\title{
A Preliminary Study on Rural Circular Economy System in Jilin
}

\author{
Liwen Zheng \\ School of Economics and Management, Changchun University of Science and Technology \\ Changchun 130022, China \\ E-mail: zhangsu1972@163.com
}

\begin{abstract}
As an important base for marketable grain and stockbreeding, Jilin pays much attention to developing its rural circular economy. Based on grey relational analysis, this paper conducts a preliminary discussion on the construction of the rural circular system in Jilin province which is intended to optimize resource utilization, to protect rural production environment and to promote sustainable development.
\end{abstract}

Keywords: Countryside, Circular economy, Grey relationship

\section{Jilin's Advantages in Developing Rural Circular Economy}

\subsection{Agricultural Advantage}

As an important base for marketable grain and stockbreeding, Jilin has produced a large amount of high-quality farming and animal products. To be exact, Jilin ranks first in per capita share of grain, commodity, off-take, export and production of marketable grain and has been in the first place on the list of per capita share of meat in China for 6 years. It has kept the records for many years of about 900-kilogram per capita share of grain, commodity rate of over $70 \%$, over 20-billion-kilogram commodity production, over 5-billion-kilogram export capacity, over 5 times the national per capita production of marketable grain average and 100-kilogram per capita share of meat. In the structure of variety and quality, there has been great improvement in both quantity and quality. Good-quality corn, rice and bean have taken up over $50 \%$ of the whole sown area; improved stockbreeding has gone to every corner of the whole province; industrial management has taken shape; an array of leading enterprises in agricultural product processing, such as Deda Company, have ranked among the top ones in the similar industries over the whole nation (Chu, 2007).

\subsection{Environmental Advantage}

Jilin has long history of agricultural production and therefore favorable natural environment. Compared with those developed provinces, it has lower degree of modernization and fewer utilized chemicals, hence less environmental pollution. Besides, its air and water pollution is not so serious as that in some developed areas in Middle and Western China. As a result, here air, water, soil and creatures make up a favorable ecosystem with strong restorability.

\subsection{Advantage in Agricultural Science and Technology}

Jilin has three colleges specializing in cultivating talents in agricultural science and technology, including Jilin Agricultural University, Agricultural College of Yanbian University and Jilin Agricultural Science and Technology College, as well as over 20 agriculture-related majors, such as Biological and Agricultural Engineering College of Jilin University, Agricultural Science of Jilin University and so on. Over the past decades, Jilin has cultivated a lot of science and technology talents who are good at production and management skills. It is shown in statistics that in 2004 there were 3.7 agricultural science and technology talents in every 10 thousand rural people in Jilin, which was over twice the national figure. Therefore, its advantage in talents has provided powerful technological support for the development of Jilin's rural circular economy (Fang, 2007).

\section{Target Location of the Construction of Jilin's Rural Circular Economy}

\subsection{Evaluation System for Jilin's Rural Circular Economy}

The evaluation system on rural circular economy provides foundation for an overall evaluation on Jilin's current situation of a harmonious development of agricultural resources, environment, economy and social system, which are independent from as well as interact with each other. Employing both quantitative and qualitative methods, we mainly draw data from Jilin Yearbook of Statistics in 2008 and establish the evaluation index system including 18 indexes. 


\subsection{Evaluation on the Construction of Jilin's Rural Circular Economy}

\subsubsection{Multilevel Grey Relational Analysis}

Grey relational analysis is based on the relation between two sequences with the purpose to examine the correlation among different factors ( $\mathrm{Li}, 2004)$. The following specific steps should be followed:

An index set involving some major evaluation indexes should be established:

$X_{i}=\left\{x_{i}(1), x_{i}(2), x_{i}(k)\right\} \mathrm{i}=1,2,3, \ldots, \mathrm{m}$

(k: the number of indexes, i: certain period of time, $X_{i}$ : the statistic sequence of evaluation indexes at the corresponding time or region)

(1) Target Sequence

Among all the sequences established at different times, we set up a target one according to the established principles. With time sequence employed in this paper, we make the final time sequence as the best one.

(2) Normalization of Indexes

Indexes can be divided into positive direction, which refers to a positive relation between the value of an index and its effect, and negative one, which goes to the other extreme.

With $x_{i}(k)$ given and $T_{\max }=\max x_{i}(k), T_{\min }=\min x_{i}(k)$ defined, normalization relation for positive indexes will be

And that for negative indexes will be

$$
y_{i}(k)=\left(x_{j}(k)-T_{\min }\right) /\left(T_{\max }-T_{\min }\right)
$$

$$
y_{i}(k)=\left(T_{\max }-x_{j}(k)\right) /\left(T_{\max }-T_{\min }\right)
$$

(3) the Calculation of correlation coefficient: the correlation coefficient between $X_{i}$ in each sequence and the corresponding index in the target sequence.

$$
\varepsilon_{i}(k)=\frac{\min _{i} \min _{j}\left|y_{0}(k)-y_{i}(k)\right|+\rho \max _{i} \max _{j}\left|y_{0}(k)-y_{i}(k)\right|}{\left|y_{0}(k)-y_{i}(k)\right|+\rho \max _{i} \max _{j}\left|y_{0}(k)-y_{i}(k)\right|}
$$

In the above formula, $\left|y_{0}(k)-y_{i}(k)\right|$ refers to the value of the absolute yield spread of $\mathrm{k}$ in the target sequence and its subsequences; min min $\left|y_{0}(k)-y_{i}(k)\right|$ refers to the minimum among the absolute yield spreads of every index of the target sequence and alli of its subsequences while $\max _{i} \max _{j}\left|y_{0}(k)-y_{i}(k)\right|$ refers to the maximum; $\rho$, the
resolution ratio, is valued as 0.5 here.

(4) Weight of Structure Index

$\mathrm{w}$, the weight of indexes at Level L in relation to those at Level L-1, should be confirmed.

(5) the Calculation of Degree of Association and Interconnection Vector

Weighed calculation of the degree of association should be conducted to examine the importance of indexes at each level for those at the upper level. The weighed degree of association in all subsequences of the target sequence should be:

$$
\mathrm{r}_{j}=\sum_{k=1}^{k} w^{(l)} \varepsilon_{i}(k)
$$

Finally comes the interconnection vector R, which enables us to have a deep comparison of the construction of circular economy at different times with multilevel grey relational analysis.

\subsubsection{Confirmation of Weight}

The following values of weight are confirmed according to multilevel grey relational analysis, as is shown in Table 2.

\subsubsection{Evaluation on Jilin's Rural Circular Economy System}

Based on the grey relational analysis on the time sequence, we selected the planned value in 2020 as our target sequence. The indexes in 2007 were lower than those in 2010 and 2013. By 2010, the indexes of economic development and social support drew near to 0.5 and that of environmental quality even exceeded 0.5 , showing Jilin's effective measures 
in environmental protection. Meanwhile, the growth in the indexes at the control level shows that Jilin's adjustments especially those in environmental protection during the Eleventh Five-Year Plan have stimulated the harmonious growth of all indexes. Only by starting from its reality in social economics and agriculture can Jilin accomplishes its harmonious development of economy and society. It is its efforts in recycling resources that provide new powerful drive for constant, harmonious and sound development of its rural economy.

It is shown in Table 3 that the indexes of recycling resources, environmental quality and social support have approached or exceeded 0.5 from 2007 to 2010, reflecting Jilin government and society's emphasis on the construction of rural circular economy as well as effective administration on environmental quality. The period from 2010 to 2013 will witness the greatest growth (0.187) in the correlation in recycling resources, showing more efforts will be made to recycle resources in rural economy. In addition, there is also growth in other aspects. To sum up, Jilin's rural circular economy has been developed into an advanced level, reflecting the positive effects a favorable rural circular economy pattern has on the whole rural environment.

\section{Policy Orientation for the Development of Jilin's Rural Circular Economy}

\subsection{Establishing an Institutional Frame for Rural Circular Economy}

\subsubsection{Government's Policy Orientation}

Rural circular economy is based on government orientation, therefore, favorable institutional environment can be created by intensifying government's policy guidance. First of all, policy support system should be perfected, mainly in input policy and land contract system, and rural security system should be improved as well to guarantee peasants' production and life, hence offering favorable support for the development of rural circular economy; second, government stimulation system should also be established, in which encouragement and punishment should both be strengthened to guide the development of rural circular economy. Only when it is possible for peasants to benefit from recycling resources and protecting the environment with the establishment of some relevant policies will rural circular economy gain rapid development.

\subsubsection{Government's Legal Support}

It is a new field to develop rural circular economy and accomplish conservation-oriented agriculture, so governments at all levels should provide support in laws, rules and regulations. Only with legislative construction will circular economy be converted from an economic theory to codes of conduct to be followed by people.

\subsubsection{Perfecting Agencies Supporting Rural Circular Economy}

Rural professional institutions should be relied on to promote the development of rural circular economy. Such organizations in China are actually agencies which perform many functions such as information consultation and transmission, technological guidance and training, serving peasants and so on. Due to their advantages in good communication with peasants, these organizations can be depended on to encourage them to develop rural circular economy.

\subsection{Exerting the Role of Economic Methods in Rural Circular Economy}

\subsubsection{Constructing a Price Regulation System of Rural Natural Resources}

First, rural land ownership should be further clarified, including rights of contract for management of land, profits from leasehold, mortgage of property and so on. Second, the prices of water resources and water supply should be fixed reasonably. Meanwhile, the compensation system for water resources protection should also be carried out to protect water resources with economic methods. Third, the evaluation of natural environment value should be conducted and a system of paying for environment utilization should be established. Only with reasonable price will rural resources be utilized properly and its circular development be promoted.

\subsection{Actively Promoting Rural Industrial Operation}

Rural industrialization, focused on marketization and intensification of rural operating activities, is a practical way to accomplish Jilin's rural circular economy. Here, the principle of "integrated, coordinated and recycling reproduction" should be followed to optimize the rural industrial structure and a complete industrial development chain with the combination of farming, stockbreeding and processing as well as that of agriculture, forestry, stockbreeding, sideline production and fisheries should be established to achieve the comprehensive goal of utilizing natural eco-resources in an overall and multilevel way and having the harmonious development of economy, ecosystem and society.

\subsubsection{Increasing Input for the Establishment of a Diversified Investment and Financing System}

First, the input for rural development should be further increased; second, rural finance system should be innovated through which financing channels can be expanded; third, more favorable conditions should be provided to attract industrial and commercial capital as well as private capital to invest in the development of rural circular economy. 


\subsection{Establishing the Philosophy for the Development of Rural Circular Economy}

Green economic accounting system should be established to promote the rapid development of circular economy. EDP refers to an accounting on environmental resources in present GDP with environmental cost and fees for protecting environmental resources excluded and some external influences taken into consideration. Therefore, Jilin should facilitate its steps in establishing its green economic accounting system and carrying it out all over the province as soon as possible (Cui, 2008).

\section{References}

Chu, Liying. (2007). A Study on Rural Industrialization in Jilin. 5.

Cui, Xin. (2008). Evitable Choice and Reflection on the Development of Rural Circular Economy in China. 5.

Fang, Min. (2007). A Study on the Development of Special Agriculture in Jilin. 5.

Li, Hongyan. (2004). Research on Grey Relational Calculation Methods. 9.

Table 1. Evaluation index system for Jilin's rural circular economy

\begin{tabular}{|c|c|c|c|c|c|}
\hline \multirow{2}{*}{$\begin{array}{l}\text { Control } \\
\text { Level }\end{array}$} & Target index system & $\begin{array}{l}\text { Current } \\
\text { situation }\end{array}$ & $\begin{array}{l}\text { Short } \\
\text { term }\end{array}$ & $\begin{array}{l}\text { Medium } \\
\text { term }\end{array}$ & Long term \\
\hline & Index level & 2007 & 2010 & 2013 & 2020 \\
\hline \multirow{3}{*}{$\begin{array}{l}\text { Reducing input of } \\
\text { resources }\end{array}$} & $\begin{array}{l}\text { X1 Chemical utilization } \\
\text { intensity (net) }\end{array}$ & 285 & 270 & 250 & 220 \\
\hline & $\begin{array}{l}\text { X2 Effective utilization rate of } \\
\text { agricultural energy }(\%)\end{array}$ & 34 & 36 & 38 & 40 \\
\hline & $\begin{array}{c}\text { X3 Chemical utilization } \\
\text { intensity in agriculture (net) }\end{array}$ & 9 & 9 & 8 & 8 \\
\hline \multirow{4}{*}{ Recycling resources } & $\begin{array}{c}\text { X4 Recovery rate of } \\
\text { agricultural plastic films }\end{array}$ & 85 & 88 & 82 & $>90$ \\
\hline & $\begin{array}{l}\text { X5 Comprehensive utilization } \\
\text { rate of straw }\end{array}$ & 78 & 80 & 82 & $>90$ \\
\hline & $\begin{array}{c}\text { X6 Recycling rate of animal } \\
\text { excrement }\end{array}$ & 35 & 41 & 45 & $>50$ \\
\hline & $\begin{array}{l}\text { X7 Recycling rate of } \\
\text { agricultural disposal }\end{array}$ & $<45$ & 60 & 70 & $>80$ \\
\hline \multirow{5}{*}{ Environmental quality } & X8 Forest acreage & 43.4 & 45 & 47.5 & $>50$ \\
\hline & X9 Area of Protected regions & 12 & $>15$ & $>18$ & $>25$ \\
\hline & $\begin{array}{c}\text { X10 Disposal rate of animal } \\
\text { excrement }\end{array}$ & 86 & 90 & 94 & 100 \\
\hline & $\begin{array}{l}\text { X11 Treatment rate of } \\
\text { degrading land }\end{array}$ & 85 & 90 & $>90$ & $>90$ \\
\hline & $\begin{array}{l}\text { X12 Comprehensive index of } \\
\text { air pollution }\end{array}$ & 3.08 & 2.87 & 2.70 & 2.21 \\
\hline \multirow{3}{*}{$\begin{array}{l}\text { Economic } \\
\text { development }\end{array}$} & $\begin{array}{l}\text { X13 Agricultural output(in } 100 \\
\text { million yuan) }\end{array}$ & 1418.90 & 1605.30 & 1805.74 & 2376.23 \\
\hline & $\begin{array}{l}\text { X14 Per capita net agricultural } \\
\text { income(yuan/person) }\end{array}$ & 4189.89 & 4350 & 5036.67 & 7085.69 \\
\hline & $\begin{array}{c}\text { X15 Drinking water } \\
\text { qualification rate in villages } \\
\text { and small towns }\end{array}$ & 70 & 90 & 95 & $>95$ \\
\hline \multirow{3}{*}{ Social support } & $\begin{array}{l}\text { X16 Contribution rate in } \\
\text { agricultural science and } \\
\text { technology }\end{array}$ & 50 & $>55$ & $>56.5$ & $>60$ \\
\hline & $\begin{array}{c}\text { X17 Government } \\
\text { administration capacity }\end{array}$ & 12.94 & 11 & 9.28 & 5 \\
\hline & X18 Engel coefficient & 40 & 38.8 & 37.6 & $<30$ \\
\hline
\end{tabular}


Note: the planning for governmental administration capacity is made with reference to Indexes for all-round Construction of a Well-off Society given by R\&D Center of the State Council of P. R. C.; the planning for the comprehensive index of air pollution as well as the contribution rate of agricultural science and technology is made according to China's Eleventh Five-Year Plan; other indexes are made according to Jilin Yearbook of Statistics in 2008; the planned target growth rate is confirmed according to Jilin's Eleventh Five-Year Plan.

Table 2. Weight of indexes for Jilin's rural circular economy

\begin{tabular}{|c|c|c|}
\hline \multirow{2}{*}{$\begin{array}{c}\text { Control } \\
\text { Level }\end{array}$} & Target index system & \multirow{2}{*}{ Weight } \\
\hline & Index level & \\
\hline \multirow{3}{*}{ Reducing input of resources } & A1 Chemical utilization intensity (net) & 0.357 \\
\hline & $\begin{array}{c}\text { A2 Effective utilization rate of agricultural } \\
\text { energy }(\%)\end{array}$ & 0.279 \\
\hline & $\begin{array}{c}\text { A3 Chemical utilization intensity in agriculture } \\
\text { (net) }\end{array}$ & 0.362 \\
\hline \multirow{4}{*}{ Recycling resources } & A4 Recovery rate of agricultural plastic films & 0.280 \\
\hline & A5 Comprehensive utilization rate of straw & 0.297 \\
\hline & A6 Recycling rate of animal excrement & 0.222 \\
\hline & A7 Recycling rate of agricultural disposal & 0.202 \\
\hline \multirow{5}{*}{ Environmental quality } & A8 Forest acreage & 0.228 \\
\hline & A9 Area of Protected regions & 0.198 \\
\hline & A10 Disposal rate of animal excrement & 0.169 \\
\hline & A11Treatment rate of degrading land & 0.203 \\
\hline & A12 Comprehensive index of air pollution & 0.206 \\
\hline \multirow{3}{*}{ Economic development } & A13 Agricultural output(in 100 million yuan) & 0.337 \\
\hline & $\begin{array}{l}\text { A14 Per capita net agricultural } \\
\text { income(yuan/person) }\end{array}$ & 0.400 \\
\hline & $\begin{array}{c}\text { A15 Drinking water qualification rate in villages } \\
\text { and small towns }\end{array}$ & 0.263 \\
\hline \multirow{3}{*}{ Social support } & $\begin{array}{l}\text { A16 Contribution rate in agricultural science and } \\
\text { technology }\end{array}$ & 0.411 \\
\hline & A17 Government administration capacity & 0.398 \\
\hline & A18 Engel coefficient & 0.191 \\
\hline
\end{tabular}

Note: these weight values are confirmed according to Bin Liu's A Study on the Development Pattern and Policy Orientation of Hebei's Rural Circular Economy.

Table 3. The correlation among indexes at different levels of Jilin's rural circular economy construction

\begin{tabular}{|c|c|c|c|c|}
\hline \multirow{2}{*}{\multicolumn{2}{|c|}{ Index }} & \multicolumn{2}{c|}{ Year } \\
\cline { 2 - 4 } & Reducing input of resources & 2007 & 2010 & 2013 \\
\cline { 2 - 5 } & Recycling resources & 0.332 & 0.388 & 0.72 \\
\cline { 2 - 5 } $\begin{array}{c}\text { Control } \\
\text { level }\end{array}$ & Environmental quality & 0.333 & 0.390 & 0.577 \\
\cline { 2 - 5 } & Economic development & 0.333 & 0.523 & 0.616 \\
\cline { 2 - 5 } & Social support & 0.332 & 0.455 & 0.604 \\
\hline \multirow{2}{*}{ Target level } & $\begin{array}{c}\text { Comprehensive level of rural } \\
\text { circular economy }\end{array}$ & 0.333 & 0.438 & 0.611 \\
\hline
\end{tabular}

